\title{
EVALUASI KETERAMPILAN BERBICARA DALAM PEMBELAJARAN BAHASA INDONESIA
}

\section{Siti Halidjah ${ }^{1}$}

\begin{abstract}
Absrak: Evaluasi keterampilan berbicara merupakan evaluasi yang rumut untuk dilaksanakan bila dibandingkan dengan evaluasi keterampilan menyimak, membaca, dan menulis. Hal ini disebabkan pajanan berbicara yang cepat hilang, sehingga diperlukan banyak waktu untuk melakukan evaluasi keterampilan ini karena yang dinilai adalah proses berbicaranya, bukan pengetahuan tentang berbicaranya. Untuk melaksanakan evaluasi keterampilan berbicara perlu diketahui hal-hal yang berkaitan dengan pengertian keterampilan berbicara, pembelajaran keterampilan berbivara, evaluasi keterampilan berbicara, sasaran evaluasi keterampilan berbicara, teknik evaluasi keterampilan berbicara, penskoran dalam evaluasi keterampilan berbicara, serta perencanaan dan pelaksanaan evaluasi keterampilan berbicara.
\end{abstract}

Kata kunci: evaluasi, keterampilan berbicara, dan pembelajaran bahasa Indonesia

\section{PENDAHULUAN}

Keterampilan berbahasa yang diajarkan di sekolah meliputi menyimak, berbicara, membaca, dan menulis. Syafi'ie (1993:25) mengemukakan bahwa keempat keterampilan berbahasa inilah yang merupakan fokus tujuan pembelajaran bahasa Indonesia. Empat keterampilan tersebut sebaliknya mendapat porsi yang seimbang dalam pengajaran (Depdikbud, 1995:3). Keseimbangan tersebut berorientasi pada tujuan atau keseimbangan yang proporsional. Oleh sebab itu, semakin banyak tujuan yang hendak dicapai, semakin banyak pula porsi pembelajaran keterampilan tersebut.

Djiwandono (1996:68) berpendapat bahwa berbicara merupakan kegiatan berbahasa yang aktif dari seorang pemakai bahasa yang menuntut prakarsa nyata dalam penggunaan bahasa untuk mengungkapkan diri secara lisan. Dalam pengertian itu, berbicara merupakan keterampilan berbahasa yang aktif-produktif. Syafi'ie (1993:25) mengemukakan bahwa berbicara merupakan keterampilan berbahasa dengan menggunakan media lisan dan

\footnotetext{
${ }^{1}$ Siti Halijah adalah dosen Jurusan Pendidikan Dasar FKIP-UNTAN Pontianak
} 
bersifat produktif. Pembelajaran berbicara di sekolah diorientasikan pada tujuan agar siswa mengungkapkan pikiran dan perasaan secara lisan sesuai dengan konteks.

Pembelajaran berbicara merupakan suatu proses yang melibatkan tiga komponen, yaitu perencanaan, pelaksanaan, dan evaluasi. Ketiga komponen tersebut berinteraksi dalam suatu sistem. Oleh sebab itu, ketiga komponen tersebut saling berkaitan secara langsung maupun tidak langsung. Tentang hal ini, Djiwandono (1996:3) mengemukanan bahwa tiga komponen tersebut mempunyai hubungan langsung dalam bentuk sebab akibat dan hubungan tidak langsung dalambentuk umpan balik.

Mata pelajaran bahasa dan sastra Indonesia adalah program untuk mengembangkan pengetahuan, keterampilan berbahasa, dan sikap positif terhadap bahasa Indonesia (Depdikbud, 1995:1). Selain itu, Oka dan Suparno (1994:47) mengemukakan bahwa pengajaran bahasa Indonesia dimaksudkan untuk membuat anak didik mampu mengintegrasikan diri dalam masyarakat Indonesia.

Pencapaian tujuan pembelajaran merupakan atah diselenggarakannya kegiatan pembelajaran. Tujuan ini menjiwai pelaksanaan peembelajaran dan juga menjiwai evaluasi pembelajaran. Tujuan yang rumuskan secara rinci dan jelas memudahkan guru untuk merencanakan dan melaksanakan pembelajaran serta memudahkan pengevaluasian ketercapaian tujuan pembelajaran. Oleh sebab itu, interaksi antarkomponen pembelajaran mengarah pada usaha mencapai tujuan pembelajaran.

Evaluasi hasil belajar adalah evaluasi yang dilakukan setelah pembelajaran. Tentang evaluasi setelah pembelajaran, Arikunto (1993:7) mengemukakan bahwa setelah selesai satu program pengajaran, guru perlu melakukan evaluasi akhir agar diketahui pencapaian tujuan pengajaran. Dalam hal ini, para pelaksana pendidikan selalu berorientasi pada tujuan pembelajaran dan tujuan tersebut selalu diarahkan pada siswa secara individual maupun kelompok.

Evaluasi merupakan proses yang sistematis yang mencakup kegiatan mengumpulkan, menganalisis, serta menafsirkan informasi untuk menentukan atau membuat keputusan tentang pencapaian tujuan pembelajaran oleh siswa. Istilah penilaian pendahuluan semakna dengan evaluasi pendahuluan, yaitu evaluasi yang dilakukan sebelum pembelajaran berlangsung.

Jika dibandingkan dengan evaluasi keterampilan menyimak, membaca, dan menulis, evaluasi keterampilan berbicara merupakan evaluasi yang rumit untuk dilakukan. Hal ini disebabkan pajanan berbicara yang cepat hilang, perlu banyak waktu untuk melakukan evaluasi keterampilan ini karena yang dinilai adalah proses berberbicaranya, bukan pengetahuan 
tentang berbicara. Oleh sebab itu dalam artikel yang berjudul "Evaluasi Keterampilan berbicara dalam PembelajaranBahasa Indonesia" penulis akan mendeskripsikan tentang pengertian keterampilan berbicara, pembelajaran keterampilan berbicara, evaluasi keterampilan berbicara, sasaran evaluasi keterampilan berbicara, teknik evaluasi keterampilan berbicara, penskoran dalam evaluasi keterampilan berbicara, serta perencanaan dan pelaksanaan evaluasi keterampilan berbicara.

\section{PEMBAHASAN}

\section{Keterampilan Berbicara}

Keterampilan berbicara merupakan salah satu keterampilan berbahasa selain menyimak, membaca, dan menulis. Secara alamiah, perolehan keterampilan tersebut dapat diurutkan dari menyimak, berbicara, membaca, dan menulis. Ketika anak masih kecil, ia membangun kompetensi komunikatif melalui kegiatan menyimak pajanan bahasa yang diucapkan oleh orang-orang di sekelilingnya dan kemudian ia belajar berbicara. Jika tidak meneruskan belajar membaca dan menulis, si anak tidak memiliki dua keterampilan tersebut.

Berbicara adalah kemampuan mengemukakan hal-hal yang terdapat dalam kehidupan sehari-hari secara lisan dengan kemudahan dan kefasihan yang memadai sehingga dapat dipahami oleh lawan bicaranya. Berbicara adalah salah satu proses pengiriman pesan kepada orang lain dengan menggunakan bahasa lisan yang secara langsung maupun tidak langsung mempunyai efek terhadap pembicara/pendengar atau keduaduanya. Djiwandono (1996:68) dan Nurgiyantoro (1995:273) mengemukakan bahwa berbicara merupakan kemampuan yang aktif produktif. Selanjutnya Djiwandono (1996:68) mengemukakan bahwa hal itu disebabkan dalam berbicara pembicara dituntut prakarsa nyata dalam menggunakan bahasa untuk mengungkapkan diri secara lisan.

Berbicara merupakan keterampilan berbahasa yang aktif. Berbicara dikatakan aktif karena pembicara melakukan aktivitas untuk menyeleksi halhal yang akan diungkapkan dan media yang digunakan. Formulasi antara isi dan media tersebut menghasilkan produk, yaitu tuturan. Oleh sebab itu, berbicara disebut keterampilan berbahasa yang aktif dan produktif.

\section{Pembelajaran Keterampilan Berbicara}

Pembelajaran bahasa yang dilandasi pendekatan komunikatif pada dasarnya belajar berbahasa. Dalam konteks pembelajaran bahasa Indonesia, sudah barang tentu bahasa yang dipelajari dan digunakan adalah bahasa Indonesia. Dalam kurikulum pembelajaran bahasa Indonesia di semua jenjang pendidikan dinyatakan pembelajaran bahasa Indonesia diarahkan untuk meningkatkan kemampuan siswa dalam berkomunikasi dengan bahasa 
Indonesia, baik lisan maupun tulisan. Dengan demikian, pembelajaran bahasa Indonesia mencakup empat keterampilan berbahasa, yaitu (1) meyimak, (2) berbicara, (3) membaca, dan (4) menulis. Ketermpilan 1 dan 2 termasuk keterampilan yang berkaitan dengan bahasa lisan, sedangkan keterampilan 3 dan 4 berkaitan dengan bahasa tilis. Keterampilan 1 dan 3 termasuk keterampilan pasif-reseptif, sedangkan keterampilan 2 dan 4 termasuk keterampilan aktif-produktif.

Pembelajaran berbicara tidak terlepas dari bermacam-macam fungsi bahasa, yaitu untuk menyatakan informasi faktual, sikap intelektual, sikap emosional, sikap moral, dan perintah. Salah satu contoh bahasa digunakan untuk menyatakan informasi faktual adalah bahasa yang digunakan untuk melaporkan suatu kejadian. menyatakan persetujuan adalah contoh pernyataansikap intelektual. Contoh pernyataan emosional adalah meminta maaf. Memperingatkan merupakan contoh bahasa yang digunakan dalam fungsi menyatakan perintah.

Belajar pada dasarnya individual karena setiap siswa memiliki karakteristik sendiri-sendiri. Pernyataan tersebut sejalan dengan pendapat Mursel dan Nasution (1995:67) yang menyatakan bahwa pelajaran harus individual karena setiap individu belajar menurut caranya sendiri. Oleh sebab itu, guru perlu mengerahui karakteristik siswa agar dapat dikembangkan sesuai dengan potensinya.

\section{Evaluasi Keterampilan Berbicara}

Evaluasi hasil pembelajaran yang baik adalah evaluasi yang menelaah hasil belajar siswa, yaitu untuk mengetahui tujuan yang telah dicapai siswa. Belajar tidak mungkin efektif kalau tidak diketahui ketercapaian tujuannya (Mursell dan Nasution, 1995:100). Selain itu, evaluasi juga berguna untuk mempertinggi hasil belajar karena hasil evaluasi dapat memotivasi siswa untuk terus belajar. Oleh sebab itu, hasil evaluasi perlu dikomunikasikan agar siswa mengetahui kelemahan dan kelebihannya terhadap hal yang sedang dipelajari. Dengan mencermati peranan dan fungsi evaluasi tersebut dapat dikatakan bahwa evaluasi merupakan bagian yang integral dalam pembelajaran.

Berkaitan dengan evaluasi dalam pembelajaran keterampilan berbicara, tingkatan evaluasi keterampilan berbicara meliputi tingkat ingatan/pengetahuan, pemahaman, dan penerapan/penggunaan (Nurgiyantoro, 1995:290-292). Evaluasi keterampilan berbicara sebaiknya diarahkan untuk mengetahui keterampilan berbicara siswa. Hal ini sejalan dengan pendekatan komunikatif yang digunakan dalam pembelajaran. Realisasinya adalah evaluasi dilakukan dengan cara menugasi siswa berbicara dan dievaluasi sesuai dengan indikator-indikator keterampilan berbicara yang telah ditentukan. Walaupun demikian, evaluasi keterampilan 
berbicara juga bisa diarahkan untuk mengevaluasi pengetahuan dan pemahaman siswa tentang hal-hal yang berkaitan dengan keterampilan berbicara.

Evaluasi mutlak diperlukan dalam pembelajaran karena hasilnya dapat memberikan umpan balik kepada guru maupun siswa. Rooijakkers (1991:11) mengemukakan bahwa guru pada umumnya kurang memikirkan perlunya umpan balik sehingga ia tidak mengetahui efek dari pengajarannya. Setelah pengajaran selesai, guru melaksanakan ujian. Bila siswa belum mengerti materi yang diajarkan karena suatu keterlambatan, guru perlu melakukan umpan balik agar dapat melakukan perbaikan dengan segera.

\section{Aspek Keterampilan Berbicara (Sasaran Evaluasi Keterampilan Berbicara)}

Ada lima komponen yang umumnya disusun dalam analisis proses berbicara, yaitu pelafalan, tatabahasa, kosakata, kelancaran, dan pemahaman. Djiwandono (1996: 68) mengemukakan bahwa aspek yang terlibat dalam berbicara adalah kosakata, tatabahasa, pelafalan, dan isi. Dengan mencermati aspek-aspek yang telah dikemukakan tersebut, masih terdapat hal yang penting yang perlu diperhatikan, yaitu aspek organisasi dan kinesik. Organisasi berkaitan dengan tata urutan penyajian pembicaraan. Aspek kinesik (mimik muka dan gerak anggota badan) juga perlu diperhatikan dalam mengevaluasi keterampilan berbicara.

Kinesik dalam berbicara secara langsung maupun tidak langsung (tetapi pendengar dapat melihat pembicara) merupakan aspek yang turut menentukan kekuatan berbicara, misalnya sorot mata dan gerakan-gerakan tangan dapat membantu pendengar untuk lebih memahami pembicaraan. Oleh sebab itu, dapat disimpulkan ada empat aspek yang perlu diperhatikan dalam mengevaluasi keterampilan berbicara, yaitu: aspek kebahasaan, pemahaman isi pembicaraan, organisasi pembicaraan, dan kinesik.

\section{Teknik Evaluasi Keterampilan Berbicara}

\section{Teknik Nontes}

Teknik nontes digunakan untuk menjaring data tentang pendapat, minat, dan kebiasaan siswa. Berkaitan dengan pembelajaran keterampilan berbicara, teknik nontes dapat digunakan untuk memperoleh data tentang aktivitas siswa ,baik di dalam kelas maupun di luar kelas. Data yang dihasilkan biasanya data kualitatif meskipun juga dalam hal tertentu datanya dikuantitatifkan, misalnya skala minat. Selain itu, teknik nontes dapat juga digunakan untuk menjaring data tentang hal-hal yangberkaitan dengan komponen-komponen pembelajaran yang lain, misalnya media, cara guru mengajar, dan lingkungan belajar. 
Sudjana (2005:67) mengemukakan bahwa alat nontes yang sering digunakan dalam mengevaluasi pembelajaran adalah kuesioner, wawancara, skala, observasi, studi kasus, dan sosiometri. Nurgiyantoro (1995:54), dalam buku Penilaian dalam Pengajaran Bahasa dan Sastra hanya membahas kuesioner, wawancara, dan pengamatan (observasi). Pertimbangan Nurgiyantoro adalah kerelevansian teknik-teknik tersebut dengan penilaian kebahasaan dan kesastraan. Dengan mempertimbangkan kemungkinan hubungannya dengan pembelajaran berbicara, teknik nontes yang akan dibahas adalah kuesioner, wawancawa, dan observasi.

\subsection{Kuesioner dan Wawancara}

Kuesioner adalah seperangkat pertanyaan/pernyataan yang ditujukan kepada siswa untuk memperoleh jawaban/tanggapan tentang halhal tertentu secara tertulis. Menurut Sudjana (2005:68), jika dilakukan secara lisan, kegiatan tersebut disebut wawancara. Oleh sebab itu, perbedaan antara kuesioner dan wawancara terletak pada media yang digunakan. Jika menggunakan media tulis disebut kuesioner, disebut wawancara jika menggunakan media lisan.

Berdasarkan cara menjawab, kuesioner dapat dibedakan menjadi dua, yaitu kuesionet berstruktur dan tak berstruktur (Ary, dkk. Terjemahan Arief Furchan, 1982:249; Nurgiyantoro, 1995:54; Arikunto, 1993:25; Sudjana, 2005:68). Wawancara pun dapat dibedakan menjadi dua seperti kuesioner tersebut. Dalam merespon kuesioner dan wawancara berstruktur, responden tinggal memilih jawaban-jawaban yang telah disediakan. Dalam merespon kuesioner atau wawancara tak berstruktur, responden dapat mengemukakan responnya secara lisan.

\subsection{Observasi atau Pengamatan}

Observasi adalah teknik evaluasi yang dilakukan dengan mengadakan pengamatan dan pencatatan terhadap sesuatu hal secara cermat. Observasi dapat digunakan untuk mengethui aktivitas berbicara siswa ketika pembelajaran berlangsung. Guru dapat mengamati siswa ketika bertanya, berdiskusi, atau ketika menjawab pertanyaan, baik yang dilakukan antarsiswa maupun siswa dengan guru. Dengan pengamatan, guru dapat memperoleh gambaran bahwa siswa tertentu aktif berbicara, kurang aktif, atau tidak aktif. data-data tersebut membantu guru dalam memberikan perlakuan pada siswa yang kurang aktif berbicara, misalnya guru memotivasi agar siswa tersebut aktif berbicara.

Observasi terhadap keterampilan berbicara siswa biasanya menggunakan observasi langsung. Dengan observasi ini, guru secara langsung mengamati perilaku berbicara siswa yang terjadi di kelas.Dalam melakukan observasi, sebaiknya guru melengkapi diri dengan pedoman 
observasi. Pedoman tersebut dapat memuat hal-hal secara umum atau hal-hal yang telah dirinci sedemikian rupa sehingga guru hanya memberikan ceklist pada kolom yang telah disediakan.

\section{Teknik Tes}

Tes adalah salah satu cara untuk mengadakan penilaian yang berbentuk suatu tugas atau serangkaian tugas yang harus dikerjakan oleh siswa atau sekelompok siswa sehingga menghasilkan suatu nilai tentang tingkah laku atau prestasi siswa tersebut, yang dapat dihubungkan dengan nilai yang dicapai oleh siswa-siswa lain atau dengan nilai standar yang telah ditetapkan. Dengan demikian, tes dapat dikatakan sebagai teknik pengumpul data. Tes merupakan alat yang tepat untuk mengukur pengetahuan dan keterampilan, termasuk keterampilan berbicara.

Dengan berpedoman pada kurikulum terbaru, yaitu Kurikulum Tingkat Satuan Pendidikan, tes berbicara sebaiknya digunakan untuk mengukur keterampilan berbicara. Realisasinya adalah diadakan tes yang menghendaki respon perbuatan (tes perbuatan), yaitu dengan meminta siswa untuk berbicara dan guru melakukan penskoran. Dengan teknik seperti ini, terjadi kesesuaian antara pembelajaran bahasa secara komunikatif dengan alat ukur yang digunakan untuk mengetahui kemampuan siswa yang berkomunikasi.

\section{Penskoran Keterampilan Berbicara}

Penskoran ketarampilan berbicara dapat dilakukan secara global/holistik dan analitik. Penskoran global adalah penskoran yang dilakukan berdasarkan kesan penskor terhadap objek yang diskor. Penskoran analitik adalah penskoran yang menggunakan detail-detail tentang aspekaspek yang diskor sebagai paduan.

Dalam konteks pembelajaran, penskoran global mengandalkan kesan guru terhadap pajanan berbicara siswa. Setelah siswa berbicara, guru dapat memberikan skor sesuai dengan kesan yang diterimanya. Kesan tersebut diwujudkan dalam bentuk angka sesuai dengan rentangan skala yang digunakan. Angka tersebut merupakan skor berbicara siswa.

Dalam penskoran analitik, skor diberikan pada setiap aspek keterampilan berbicara yang dijadikan sasaran evaluasi. Aspek-aspek yang menjadi sasaran evaluasi perlu dideskripsikan secara mendetail agar dapat membantu guru dalam memberikan skor terhadap pajanan siswa. Besarnya skor untuk masing-masing aspek bergantung pada pertimbangan guru. Pedoman penskoran dapat dimodifikasi oleh guru sesuai dengan kebutuhan evaluasi. 


\section{Perencanaan dan Pelaksanaan Evaluasi Keterampilan Berbicara}

Evaluasi merupakan kegiatan yang sistematis dan terintegrasi dalam pembelajaran. Oleh sebab itu, evaluasi perlu direncanakan dan dilaksanakan dengan baik untuk mengoptimalkan pembelajaran. Nurkancana dan Sunartana (1992: 26-30) mengemukakan bahwa perencanaan evaluasi meliputi empat kegiatan, yaitu merumuskan tujuan, menetapkan aspek yang dinilai, menetapkan metode, dan menyiapkan alat-alat. Perencanaan bertujuan untuk menentukan ruang lingkup bahan pembelajaran dan perubahan perilaku yang diharapkan, menyiapkan bahan/alat penilaian sesuai dengan sasaran atau objek penilaian dan cara penilaian. Sasaran penilaian yang dimaksud adalah siswa sesuai dengan tingkatan kemajuan belajar dan tahapan penilaian.

Tujuan evaluasi merupakan bagian yang sangat penting kerana merupakan pijakan dalam merencanakan kegiatan-kegiatan selanjutnya. Langkah pertama dalam perencanaan evaluasi keterampilan berbicara adalah menentukan ruang lingkup. Dalam tes berbicara, tujuan evaluasi dapat diarahkan untuk mengukur salah satu wujud keterampilan berbicara, misalnya pidato. Dengan membatasi ruang lingkup tersebut, secara otomatis telah mengarahkan perencanaan evaluasi, yaitu mengevaluasi hal-hal yang berkaitan dengan pidato.

Langkah kedua dalam perencanaan adalah menetapkan aspekaspek yang hendak dievaluasi. Penetapan ini didasarkan pada tujuan evaluasi. Dengan ditetapkannya tujuan dan aspek-aspek yang dievaluasi, guru dapat menentukan teknik evaluasi yang tepat agar tujuan evaluasi tercapai.

Langkah terakhir adalah menyiapkan alat-alat evaluasi. Al;at-alat yang diperlukan bergantung pada teknik evaluasi yang digunakan, misalnya guru menggunakan tes perbuatan dalam mengevaluasi keterampilan berbicara, maka alat-alat yang dipersiapkan adalah lembar penskoran, indikator penskoran, dan alat-alat yang menunjang kegiatan berbicara (sesuai dengan jenis berbicara yang ditampilkan siswa).

Dalam pelaksanaan evaluasi terdapat kegiatan mengumpulkan data, penskoran, menafsirkan skor, dan membuat keputusan. Sebagai contoh kegiatan mengumpulkan data adalah guru mengadakan tes perbuatan untuk mengetahui keterampilan berbicara siswa. Kegiatan ini dilaksanakan dengan cara meminta siswa untuk tampil berbicara. Selanjutnya, dilakukan penskoran terhadap tampilan siswa tersebut. Skor yang diperoleh siswa merupakan skor mentah. Agar skor tersebut bermakna, perlu ditafsikan dengan menggunakan pedoman penafsiran skor yang telah disusun. Skor yang telah ditafsirkan tersebut dapat digunakan sebagai dasar menentukan tingkat keterampulan berbicara siswa. Setelah diketahui tingkat keterampilan 
berbicara siswa, guru dapat membuat suatu keputusan yang berkaitan dengan usaha meningkatkan keterampilan berbicara siswa.

Berkaitan dengan penafsiran skor, ada dua cara yang dapat digunakan untuk menafsirkan skor tes, yaitu berdasarkan acuan patokan dan berdasarkan acuan norma. Namun, dalam evaluasi hasil belajar, skor siswa lebih cocok bila ditafsirkan berdasarkan acuan patokan. Hal ini disebabkan evaluasi hasil belajar dimaksudkan untuk mengetahui ketercapaian tujuan pembelajaran, bukan untuk mengetahui posisi siswa dalam kelompoknya.

\section{PENUTUP \\ Simpulan}

Berdasarkan uraian pada bagian pembahasan di atas, simpulan yang dapat diambil adalah sebagai berikut.

1) Berbicara merupakan keterampilan berbahasa aktif dan produktif.

2) Ada empat aspek yang perlu diperhatikan dalam mengevaluasi keterampilan berbicara, yaitu aspek kebahasaan, pemahaman isi pembicaraan, organisasi pembicaraan, dan kinesik (mimik muka dan gerak anggota badan).

3) Teknik yang dapat digunakan dalam evaluasi keterampilan berbicara adalah teknik nontes (kuesioner dan wawancara) dan teknik tes (tampilan/perbuatan).

4) Penskoran keterampilan berbicara dapat dilakukan secara global/holistik dan analitik/per aspek.

5) Langkah-langkah dalam perencanaan evaluasi keterampilan berbicara adalah menentukan/membatasi ruang lingkup, menetapkan aspek-aspek yang hendak dievaluasi, dan menyiapkan alat-alat evaluasi.

6) Dalam ealuasi hasil belajar (termasuk tes ketarampilan berbicara), skor siswa lebih cocok ditafsirkan berdasarkan acuan patokan. Hal ini disebabkan evaluasi hasil belajar tersebut ditujukan untuk mengetahui memampuan siswa atau ketercapaian tujuan pembelajaran.

\section{DAFTAR PUSTAKA}

Arikunto, Suharsimi. 1993. Dasar-Dasar Evaluasi Pendidikan. Jakarta: Bumi Aksara.

Ary, Donald, Jacobs, L.C. dan Razavieh, A. Tanpa Tahun. Pengantar Penelitian dalam Pendidikan. Terjemahan oleh Arief Furchan. 1982. Surabaya: Usaha Nasional.

Depdikbud. 1995. Kurikulum Sekolah Menengah Umum: Petunjuk Teknik Mata Pelajaran: Bahasa Indonesia. Jakarta: Depdikbud. 
Djiwandono, M. Sunardi. 1996. Tes Bahasa dalam Pengajaran. Bandung: IKIP Bandung.

Mursel, J. dan Nasution, S. 1995. Mengajar dengan Sukses (Succesful Teaching). Jakarta: Bumi Aksara.

Nurgiyantoro, Burhan. 1995. Penilaian dalam Pengajaran Bahasa dan Sastra. Yogyakarta: BPFE.

Nurkancana, Wayan dan Sunartana, PPN. 1992. Evaluasi Hasil Belajar. Surabaya: Usaha nasional.

Oka, I.G.N. dan Suparno. 1994. Linguistik Umum. Jakatra: Depdikbud.

Rooijakkers, Ad. Tanpa Tahun. Mengajar dengan Sukses Petunjuk Merencanakan dan Menyampaikan Pengajaran. Terjemahan oleh Soenoro. Jakarta: Grasindo.

Sudjana, Nana. 2005. Penilaian Hasil Proses Belajar Mengajar. Bandung: Remaja Rosdakarya.

Syafi'ie, Imam. 1993. Terampil Berbahasa Indonseia 1 Petunjuk Guru Bahasa Indonesia Sekolah Menengah Umum Kelas 1. Jakrta: Depdikbud. 